\title{
Sensitivity and specificity of indirect ELISA for the detection of antibody titers against BVDV from beef cattle raised in Pará State
}

\author{
Sensibilidade e especificidade do ELISA indireto na deteç̧ão de \\ anticorpos anti-BVDV em bovinos de corte criados no \\ Estado do Pará
}

\author{
Rinaldo Batista Viana ${ }^{1 *}$; Aline do Socorro Lima Kzam²; Bruno Moura Monteiro ${ }^{3}$; \\ Cláudio Cabral Campello"; Eliomar de Moura Sousa²; Damazio Campos de Souza; \\ Liria Hiromi Okuda ${ }^{6}$; Edviges Maristela Pituco ${ }^{6}$; José Dantas Ribeiro Filho ${ }^{7}$
}

\begin{abstract}
The aims of this study were to establish the prevalence of anti-bovine viral diarrhea virus (BVDV) antibodies $(\mathrm{Ab})$ in beef cattle raised in Pará state, to compare the prevalence of seropositive animals to BVDV using a commercial indirect enzyme-linked immunosorbent assay kit (iELISA) and the virus neutralization (VN) test, and finally, to determine the sensitivity (Se) and specificity (Sp) of the iELISA for the detection of anti-BVDV Ab using VN as a gold standard. A total of 400 serum blood samples from Nelore cows aged at least 24 months from five farms in the Pará state from two mesoregions (Metropolitan Region of Belem and Northeast of Pará) were analyzed. All animals were vaccinated against brucellosis and foot-and-mouth disease. The examination of anti-BVDV Ab with VN was performed in the Laboratory of Bovine Viruses of the Biological Institute of Sao Paulo as described in the Manual of Diagnostic Tests and Vaccines for Terrestrial Animals. For VN, bovine kidney epithelial cells from the Madin Darby Bovine Kidney (MDBK) strain were used. The determinations of anti-BVDV $\mathrm{Ab}$ were performed with the iELISA test at the Laboratory of Immunology and Microbiology of the Federal Rural University of Amazonia according to the manufacturer's recommendations. The results were classified as follows: (a) correct positive diagnosis, (b) incorrect positive diagnosis, (c) correct negative diagnosis, and (d) incorrect negative diagnosis, according to the results obtained from VN. From the values obtained from VN and iELISA, Se [(a $\div \mathrm{a}+\mathrm{d}) \times 100]$, Sp $[(\mathrm{c} \div \mathrm{c}+\mathrm{b}) \times 100]$, positive predictive value $[(\mathrm{a} \div \mathrm{a}+\mathrm{B}) \times 100]$, and negative predictive value $[(\mathrm{c} \div \mathrm{c}+\mathrm{d}) \times 100]$ were calculated for iELISA. The frequencies (\%) of seropositive animals were determined and compared both between the different tests (iELISA and VN) and between the different farms (1, 2, 3, 4, and 5). The statistical analysis was performed with a significance level of $5 \%$. The prevalence of seropositive animals was found to be different $(\mathrm{P}<0.0001)$ using VN $(39.25 \%$ [157/400]) and iELISA $(54.50 \%$ [218/400]). It was observed that the Se and Sp of the iELISA assay were $98.72 \%$ and $74.07 \%$, respectively. Of the total,
\end{abstract}

${ }^{1}$ Prof., Instituto da Saúde e Produção Animal, Universidade Federal Rural da Amazônia, UFRA, Belém, PA, Brasil. E-mail: rinaldovianna@hotmail.com

2 Médicos Veterinários, Discentes de Mestrado, Programa de Pós-graduação em Saúde e Produção Animal na Amazônia, UFRA, Belém, PA, Brasil. E-mail: alinekzam@hotmail.com; eliomar.sousa@gmail.com

3 Prof., UFRA, Campus de Paragominas Ufra, Paragominas, PA, Brasil. E-mail: brunomouramonteiro@hotmail.com

${ }^{4}$ Prof., Faculdade de Veterinária, Universidade Estadual do Ceará, UECE, Fortaleza, CE, Brasil. E-mail: claudio.campello@uece.br

5 Pós-graduando Programa de Pós-Graduação em Medicina Veterinária, Faculdade de Ciências Agrárias e Veterinárias, Universidade Estadual Paulista "Júlio de Mesquita Filho, campus de Jaboticabal, Unesp, Jaboticabal, SP, Brasil, damazio.souza@hotmail.com

${ }^{6}$ Pesquisadoras, Laboratório de Viroses de Bovídeos, Instituto Biológico de São Paulo, São Paulo, SP, Brasil. E-mail: okuda@, biologico.sp.gov.br; empituco@gmail.com

7 Prof., Programa de Pós-graduação em Medicina Veterinária, Departamento de Medicina Veterinária, Universidade Federal de Viçosa, UFV, Viçosa, MG, Brasil. E-mail: dantas@ufv.br

* Author for correspondence 
$25.93 \%(63 / 243)$ of the samples were considered false-positive and $1.27 \%$ false-negative $(2 / 157)$. It was concluded that the BVDV infection is present in beef cattle herds of the state of Para. Based on the speed of execution, ease of handling, and high Se of the iELISA, it is suggested that this assay can be used as a screening test for the detection of anti-BVDV Ab with the aim of eliminating infected animals from large herds of beef cattle.

Key words: Beef cattle. ELISA. Sensibility. Specificity. Viral diarrhea. Virus neutralization.

\section{Resumo}

Para se estabelecer a prevalência de anticorpos (Ac) anti-BVDV em rebanhos bovinos de corte no Estado do Pará e comparar a prevalência de animais soropositivos para o BVDV utilizando-se um kit comercial de ELISA-I ("Enzyme-linked Immunosorbent Assay" indireto) frente ao teste de VN (virusneutralização) e determinar a Se (sensibilidade) e Sp (especificidade) do ELISA-I para detecção de Ac anti-BVDV frente a VN, foram analisadas 400 amostras de soros sanguíneos de vacas Nelore com idade mínima superior a 24 meses, vacinadas contra brucelose e febre aftosa, provenientes de cinco fazendas no estado do Pará, localizadas em duas Mesorregiões (Metropolitana de Belém e do Nordeste Paraense). A pesquisa de Ac anti-BVDV determinados pela VN foi realizada no Laboratório de Viroses de Bovídeos do Instituto Biológico de São Paulo, conforme descrito no Manual of Diagnostic Tests and Vaccines for Terrestrial Animals. Foram utilizadas células epiteliais de rim bovino da linhagem Madin Darby Bovine Kidney - MDBK). Já as determinações dos Ac anti-BVDV pelo ELISA-I foram realizadas no Laboratório de Imunologia e Microbiologia da Universidade Federal Rural da Amazônia, conforme recomendações do fabricante. Os resultados verificados foram classificados como diagnóstico positivo correto (a), diagnóstico positivo incorreto (b), diagnóstico negativo correto (c), diagnóstico negativo incorreto (d), em função dos resultados obtidos na VN. A partir desses valores, calculou-se para o ELISA-I a sensibilidade [ $(\mathrm{a} / \mathrm{a}+\mathrm{d}) \times 100]$, a especificidade [ $(\mathrm{c} / \mathrm{c}+\mathrm{b}) \times 100]$, o valor preditivo positivo $[(a / a+b) \times 100]$ e o valor preditivo negativo $[(c / c+d) \times 100]$. Foram determinadas as frequências (\%) de animais positivos, tanto entre os testes (ELISA-I e VN) como entre as diferentes fazendas (1, 2, 3, 4 e 5). A estatística de inferência foi realizada com nível de significância de $5 \%$. A prevalência de animais soropositivos foi diferente $(\mathrm{P}<0,0001)$ entre os teste de VN $[39,25 \%(157 / 400)]$ e ELISA-I [54,50\% (218/400)]. Observou-se que os valores de Se e Sp do ELISA-I corresponderam a 98,72\% e $74,07 \%$, e que $25,93 \%$ (63/243) das amostras foram falso-positivas e 1,27\% (2/157) falso-negativas. Concluiu-se que a infecção pelo BVDV está presente em rebanhos de corte do estado do Pará. Devido à rapidez, praticidade e alta sensibilidade do ELISA-I, sugere-se que este teste seja utilizado como teste de triagem para a deteç̧ão de Ac anti-BVDV, visando identificar os animais infectados de grandes rebanhos de bovinos de corte.

Palavras-chave: Bovinos de corte. Diarreia viral. ELISA. Especificidade. Sensibilidade. Virusneutralização.

\section{Introduction}

Bovine viral diarrhea (BVD) is known as one of the most important diseases that is responsible for economic losses in beef and dairy herds worldwide (ALTAMIRANDA et al., 2012). The disease is caused by the bovine viral diarrhea virus (BVDV), which reduces production parameters (RODNING et al., 2012) and reproductive efficiency of the herd (GROOMS, 2006).

BVDV isolates can be classified according to the ability to produce cytopathology in cell culture, for example, cytopathic or cytopathogenic (CP) and non-cytopathic or non-cytopathogenic (NCP) biotypes. The majority of viruses are NCP, whereas $\mathrm{CP}$ samples are isolated almost exclusively in animals suffering from mucosal disease (MD), a severe clinical form of the infection (BROWNLIE, 1990; BAKER, 1995). The isolates of BVDV present a great antigenic variability, and two antigenically distinct genotypes have already been identified: BVDV-1 and BVDV-2 (VILCEK et al., 
2001). There is a growing awareness of another atypical or HoBi-like pestivirus (BVDV-3), which is also associated with clinical disease in cattle (BAUERMANN et al., 2013; MARQUES et al., 2016).

The two genotypes can be differentiated from each other and other pestiviruses using monoclonal antibodies (MAb) directed against major glycoproteins E2 and ERNS or by using genetic analysis. The reverse transcription reaction, followed by polymerase chain reaction (RT-PCR), allows identification of the virus directly from blood samples (LETELLIER; KERKHOFS, 2003).

Although the BVD shows some characteristic clinical signs, often some animals are asymptomatic carriers, and a conclusive diagnosis is not always possible based only on physical examination and clinical signs of the animal (GOYAL, 2005). Thus, complementary tests may contribute to the studies on the prevalence and / or agent identification (direct virus search). Among these laboratory tests, there is virus neutralization (VN), which is considered the gold standard technique for detecting anti-BVDV $\mathrm{Ab}$ and has been used globally (DUBOVI, 2013; OIE, 2015).

The lack of standardization (e.g., different viral strains, cells, and protocols used) performed in different laboratories may make it difficult to compare and interpret results of the diagnostic tests for BVD (FLORES et al., 2005). Most Brazilian laboratories that perform the VN test for BVDV use only strains of North American origin (Singer and NADL). Using only one strain for identification is not ideal because low levels of antibodies against BVDV-2 may not be detected when using type 1 and vice versa (FULTON et al., 1997). Thus, it is important to use both genotypes, not only BVDV-1 or 2, as this may lead to fewer seroreactive animals (OIE, 2015).

$\mathrm{VN}$ is considered a highly specific technique (OIE, 2015) and may be recommended to identify the presence of specific neutralizing agents, depending on the viral strain to be used, as well as to measure them, constituting a laborious and time-consuming technique (DUBOVI, 2013). The indirect immunosorbent assay (iELISA) kit uses both BVDV genotypes 1 and 2 and presents good applicability, agility, and practicality for the seroepidemiological diagnosis of BVDV (OIE, 2015). Therefore, when considering the peculiarities of each test, the iELISA may be more reproducible and economically viable than the VN test (GONDA et al., 2012; LARSKA et al., 2013). In this manner, the iELISA could be recommended for the diagnosis of a large number of samples, as well as to quantify the presence of anti-BVDV Ab.

In this study, it was hypothesized that a similar prevalence is obtained using both iELISA and VN and that the sensitivity ( $\mathrm{Se}$ ) and $\mathrm{Sp}(\mathrm{Sp}$ ) of the iELISA are high $(>90 \%)$ when compared to the gold standard VN test for anti-BVDV Ab detection. Thus, the objectives of this research were: (1) to identify the prevalence of anti-BVDV Ab in beef cattle herds in two mesoregions of Pará state; (2) to compare the prevalence of seropositive animals to BVDV using a commercial iELISA kit compared to $\mathrm{VN}$; and (3) to determine the Se and Sp of the iELISA for the detection of anti-BVDV Ab against the VN test.

\section{Material and Methods}

During the period from March to May of 2013, a descriptive, analytical study was carried out with 400 female Nelore (Bos taurus indicus) cows aged greater than 24 months with at least one previous calving. The animals came from five farms; of which, two are located in the Metropolitan Region of Belém mesoregion in the municipalities of Castanhal (1017'53.98 "S 47055'01.78” O) and Santa Izabel do Pará (1017'53.54 “S 48009'25.36" W), and three are located in the mesoregion of Northeast of Pará - in the municipalities of São Francisco do Pará (1010’08.67 “S 47048’44.00” W), Garrafão do Norte (1o55'48.79 “S 47o03'03.28” O) and 
Capitão Poço (1o25 ‘458.63 “S 48o09'45.08” W), as described in Table 1. All farms had a breeding station done with artificial insemination followed by natural mating of the non-pregnant females with farm bulls. Sanitary management included regular worm control and vaccinations against footand-mouth disease, symptomatic carbuncle, and brucellosis. All the properties presented a history of abortion, however, sporadically.
$\mathrm{Ab}$ analyses were performed using blood samples collected via jugular venipuncture after local antisepsis using $25 \times 0.8 \mathrm{~mm}$ disposable needles and $10 \mathrm{~mL}$ siliconized vacutainer tubes without anticoagulants. The clot retraction occurred at room temperature, and then, the tubes were centrifuged for $15 \mathrm{~min}$ at $2500 \mathrm{x}$ g. Blood sera were then aliquoted into $1.5 \mathrm{~mL}$ microtubes and stored at $-20{ }^{\circ} \mathrm{C}$ for further analysis.

Table 1. Description of study sites and sampling in each herd according to farm and municipality.

\begin{tabular}{ccc}
\hline FARM & MUNICIPALITY & SAMPLING / HERD (\%) \\
\hline 1 & Castanhal & $80 / 1,300(6.15 \%)$ \\
2 & São Francisco do Pará & $80 / 600(13.33 \%)$ \\
3 & Garrafão do Norte & $80 / 700(11.42 \%)$ \\
4 & Santa Izabel & $80 / 2,500(3.20 \%)$ \\
5 & Capitão Poço & $80 / 2,500(3.20 \%)$ \\
\hline
\end{tabular}

The VN technique was performed at the Laboratory of Bovine Viruses of the Biological Institute of São Paulo, as described in the Manual of Diagnostic Tests and Vaccines for Terrestrial Animals (OIE, 2015). Madin Darby Bovine Kidney (MDBK) epithelial cells were used. The cells were cultured in minimal essential medium (MEM) containing penicillin (1.6 mg L-1), streptomycin (0.4 mg L-1), and nystatin (0.02 mg L-1) supplemented with $10 \%$ of equine serum. For analysis of the titers of $\mathrm{Ab}$, flat bottom polystyrene 96-well plates were used, where the samples were serially diluted in logarithmic base 2, from the 1:10 dilution to 1 : 5,120, using MEM medium. All samples were tested in duplicates. After adding the viral suspension containing 100DICT50 of the NADL cytopathic BVDV-1 strain (BVDV type 1) virus, the plates were incubated for one hour in an oven at $37{ }^{\circ} \mathrm{C}$ with $5 \% \mathrm{CO}_{2}$. After this time, $50 \mu \mathrm{L}$ of MDBK cell suspension at the concentration of $3 \times 10^{5} \mathrm{~mL}$ cells was added in each well. Samples were read after 96 $\mathrm{h}$ considering reactive the samples that showed total neutralization of 100DICT50 of BVDV starting from the 1:10 dilution. The test was validated by the control of cells, control of sera, control of doses, results of control sera, and retrotitulation results by the method of Reed and Muench (1938).

The same samples were also tested for antiBVDV Ab with iELISA kit (BVDV-1 and BVDV-2 genotypes) (Bovine Viral Diarrhoea Virus - BVDV - Antibody Test, IDEXX Laboratories, Westbrook, Maine, $\mathrm{USA}^{8}$ ). The analyzes were done at the Laboratory of Immunology and Microbiology of the Federal Rural University of Amazônia, following the protocol recommended by the manufacturer. For the calculations of the prevalence, Se, Sp, and positive and negative predictive values of the tests, the samples considered suspect on the iELISA were counted as positive. The results verified using the iELISA were classified as (a) correct positive diagnosis, (b) incorrect positive diagnosis, (c) correct negative diagnosis, and (d) incorrect negative diagnosis, when compared to the VN results. From these iELISA values, the $\mathrm{Se}$

\footnotetext{
8 IDEXX BVDV Total Ab Test Part Number: 06-44000-04 (C) 2013 IDEXX Laboratories, Inc. All rights reserved. IDEXX Laboratories, Inc. One IDEXX Drive, Westbrook, Maine 04092, United States.
} 
$[(\mathrm{a} \div \mathrm{a}+\mathrm{d}) \times 100]$, Sp $[(\mathrm{c} \div \mathrm{c}+\mathrm{b}) \times 100]$, positive predictive value $[(\mathrm{a} \div \mathrm{a}+\mathrm{b}) \times 100]$, and negative predictive value $[(\mathrm{c} / \mathrm{c}+\mathrm{d}) \times 100]$ were calculated, as described by Karen et al. (2011). For the values of $\mathrm{Se}, \mathrm{Sp}$, and positive and negative predictive values, the following classification was considered: 0-40\% (very low), 40-70\% (low), 70-90\% (average), and 90-100\% (high).

Descriptive statistics of the data, represented by the frequencies (\%) of positive or negative animals, both between the examinations and between the different farms, were obtained using the Freq procedure of the program SAS version 9.2 (SAS / STAT, SAS Institute Inc., Cary, NC). The inference statistic was performed as analysis of variance (ANOVA) using the mixed analysis procedure Glimmix from the SAS program. The test variables, (VN and iELISA), Farm (1, 2, 3, 4, and 5), as well as the Test * Farm interaction, were included in the statistical model. A comparison between the frequencies of the groups was performed using the SAS lsmeans/pdiff ilink lines feature of the SAS, using a significance level of $5 \%$.

\section{Results and Discussion}

The prevalence of seropositive animals as determined using VN was 39.25\% (157/400) (Table 2). This occurrence was lower than the $98 \%$ (204/208) observed by Junqueira et al. (2006) in female beef cattle (Nelore and Red Angus x Nelore) aged over 24 months from the west of São Paulo state and the $64 \%(2,261 / 3,533)$ related by Brito et al. (2010) in female cattle older than 24 months from different regions of the Goiás state. This lower prevalence obtained in the present study can be attributed to the different cutoff points used in the $\mathrm{VN}$ technique, and by the fact that the authors of previous studies considered positive animals with Ab titration $\geq 8$ and $\geq 4$, respectively, while in the present study a cutoff point $\geq 10$ was assumed.

Table 2. Results of the virus neutralization (VN) and iELISA BVDV total Ab tests for the detection of Ab against bovine viral diarrhea virus in serum samples.

\begin{tabular}{ccc}
\hline \multirow{2}{*}{ RESULTS } & \multicolumn{2}{c}{ TESTS } \\
\cline { 2 - 3 } & VN (\%) & iELISA BVDV Total Ab Test (\%) \\
\hline \multirow{2}{*}{ Seropositive animals } & $39.25^{\mathrm{b}}$ & $54.50^{\mathrm{a}}$ \\
Seronegative animals & $(157 / 400)$ & $(218 / 400)$ \\
& $60.75^{\mathrm{a}}$ & $45.50^{\mathrm{b}}$ \\
TOTAL & $(243 / 400))$ & $(182 / 400)$ \\
& 100 & 100 \\
& $(400 / 400)$ & $(400 / 400)$ \\
\hline
\end{tabular}

Different lowercase letters between columns represent $\mathrm{P}<0.0001$.

iELISA, indirect enzyme-linked immunosorbent assay; BVDV, bovine viral diarrhea virus, Ab, antibody.

In addition, differences may occur due to factors such as raising conditions, animal management, soil and climatic conditions, mechanical milking, use of artificial insemination or artificial insemination associated with natural mating, use of parental pickets, absence of veterinary assistance, age, sex, and breed of the animals (QUINCOZES et al., 2007; SOUSA et al., 2013; PASQUALOTTO et al., 2015). Table 3 confirms these previous findings; it displays a variation in the prevalence of BVDV infection according to the different properties studied using both VN and iELISA. Furthermore, Table 3 also shows that, in most of the properties, the iELISA identified the prevalence of anti-BVDV $\mathrm{Ab}$ better than $\mathrm{VN}$, which suggests that the iELISA was able to identify the genotype BVDV- 2 since only the NADL strain (BVDV type 1 genotype) was identified using the $\mathrm{VN}$ test. 
Dias et al. (2010) investigated the prevalence of anti-BVDV-1 $\mathrm{Ab}$ and anti-BVDV-2 $\mathrm{Ab}$ in 1,925 serum samples obtained from herds from different regions of the São Paulo state that were naturally infected and unvaccinated against BVDV. In different production systems, previous studies detected a larger prevalence of seropositive animals $(62.8 \%$ of animals reactive to the two genotypes, $2.65 \%$ reacted only against BVDV-1, and 3.5\% only to BVDV-2) than that reported in this study. These results proved the dissemination of the two genotypes in the herds of the state of São Paulo and showed that it is of fundamental importance to include both genotypes in the VN tests performed by Brazilian laboratories. As well as the use of Brazilian isolates strains, since there is huge antigenic variability in relation to North American and European BVDV strains (DIAS et al., 2010; DUBOVI, 2013). It is worth noting that most of the Brazilian laboratories that perform the $\mathrm{VN}$ test for BVDV use only BVDV-1 strains of North American origin (Singer and NADL) (OIE, 2015).

Table 3. Prevalence of bovine viral diarrhea virus (BVDV) infection in the different properties studied according to the virus neutralization $(\mathrm{VN})$ and iELISA BVDV Total Ab tests.

\begin{tabular}{cccc}
\hline \multirow{2}{*}{ MESOREGIONS } & FARM & \multicolumn{2}{c}{ TESTS } \\
\cline { 3 - 4 } & MUNICIPALITY & VN (\%) & $\begin{array}{c}\text { iELISA BVDV Total Ab } \\
\text { Test (\%) }\end{array}$ \\
\hline \multirow{2}{*}{ Metropolitan Region of Belém } & $\mathbf{1}$ & $13.75^{\mathrm{e}}$ & $40.00^{\mathrm{cd}}$ \\
& Castanhal & $(11 / 80)$ & $(32 / 80)$ \\
& $\mathbf{2}$ & $15.00^{\mathrm{de}}$ & $32.50^{\mathrm{c}}$ \\
& São Francisco do Pará & $(12 / 80)$ & $(26 / 80)$ \\
Northeast of Pará & $\mathbf{3}$ & $80.00^{\mathrm{ab}}$ & $85.00^{\mathrm{a}}$ \\
& Garrafão do Norte & $(64 / 80)$ & $(68 / 80)$ \\
& $\mathbf{4}$ & $0.00^{\mathrm{e}}$ & $23.75^{\mathrm{cd}}$ \\
& Santa Izabel & $(0 / 80)$ & $(19 / 80)$ \\
& $\mathbf{5}$ & $87.50^{\mathrm{b}}$ & $91.25^{\mathrm{ab}}$ \\
& Capitão Poço & $(70 / 80)$ & $(73 / 80)$ \\
\hline
\end{tabular}

Different lowercase letters on the same line have significant differences between them (P test $<0.0001$; P Farm $<0.0001$; P Test * Farm $=0.01$ ).

iELISA, indirect enzyme-linked immunosorbent assay; Ab, antibody.

Furthermore, 101 of the 400 samples $(25.25 \%)$ had an antibody titer $\geq 80$ on VN (Table 4 ). This can be because of the presence of animals in the acute phase of the disease and/or persistently infected animals (PIs), (STURZA et al., 2011) since herds that have PIs can be identified using serology, as the presence of the virus results in high levels of antibodies in most animals (HOUE, 1999). It is also worth noting that iELISA presented a positive result for all samples with an antibody titer $\geq 80$ on VN. 
Table 4. Distribution of Ab titers in the virus neutralization test (VN) and the respective optical density (OD) of the serum samples using the iELISA BVDV Total Ab Test.

\begin{tabular}{cccc}
\hline \multirow{2}{*}{ VN (TITER) } & \multicolumn{2}{c}{ iELISA BVDV Total Ab Test $($ OD) } & \multirow{2}{*}{ TOTAL } \\
\cline { 2 - 3 } & $<0.200^{1}(\%)$ & $\geq 0.300^{2}(\%)$ & $243(60.75)$ \\
$\geq 10$ & $180(45.00)$ & $63(15.75)$ & $10(2.50)$ \\
$\geq 10$ & $1(0.25)$ & $9(2.25)$ & $20(5.00)$ \\
$\geq 40$ & $1(0.25)$ & $19(4.75)$ & $26(6.50)$ \\
$\geq 80$ & 0 & $26(6.50)$ & $42(10.50)$ \\
$\geq 160$ & 0 & $42(10.50)$ & $27(6.75)$ \\
$\geq 320$ & 0 & $27(6.75)$ & $21(5.25)$ \\
$\geq 640$ & 0 & $21(5.25)$ & $07(1.75)$ \\
$\geq 1,280$ & 0 & $07(1.75)$ & $02(0.50)$ \\
$\geq 2,560$ & 0 & $02(0.50)$ & $02(0.50)$ \\
TOTAL & 0 & $02(0.50)$ & $400(100)$ \\
\hline
\end{tabular}

${ }^{1}$ Negative samples; ${ }^{2}$ positive samples.

iELISA, indirect enzyme-linked immunosorbent assay; BVDV, bovine viral diarrhea virus, Ab, antibody.

The seropositivity to BVDV on the iELISA test was $54.50 \%$ (218/400) (Table 2). A similar result was described by Freitas et al. (2011) in Maranhão state in 91 crossbred females without vaccination against BVDV from an extensive breeding system. Freitas et al. (2011) observed 37.37\% (34/91) of positive animals and $18.68 \%$ (17/91) of suspect animals (totaling 56.04\% [51/91] of seroreactive animals). In contrast, a higher prevalence of seroreactive animals using iELISA was described by Chaves et al. (2010) $(61.5 \%, 246 / 400)$ and Sousa et al. (2013) $(67.30 \%, 105 / 156)$ in dairy herds unvaccinated against BVDV in the Maranhão state. These results suggest a lower prevalence of infection in beef cattle, probably due to the shorter period of stay of the animals on the properties, and consequently, the lesser direct contact of susceptible animals to infected animals. Extensive systems, as well as the management, can influence the occurrence of the infection (QUINCOZES et al., 2007; PASQUALOTTO et al., 2015).

All prevalence values described above agree with the estimates of the prevalence of $\mathrm{Ab}$ against BVDV in the bovine population, which ranges from $50 \%$ to $90 \%$ (HOUE, 1999). The data obtained that suggest a higher BVDV infection rate in dairy herds than in beef cattle may be related to the fact that the dairy herds' lifespan is higher than those in beef farms. One finding that reinforces this hypothesis is that the seropositivity increases according to the age of the animals. Alexandrino et al. (2011) observed a BVDV prevalence of $40 \%$ (14/35) in calves, $73.9 \%$ $(48 / 65)$ in young animals, and $74.2 \%(132 / 178)$ in adult bovines, which would favor horizontal and vertical transmission of the virus.

The prevalence of $39.25 \%$ (157/400) BVDV seropositive animals on $\mathrm{VN}$ was lower $(\mathrm{P}<0.0001)$ than the $54.50 \%(218 / 400)$ in reagent samples obtained on iELISA (Table 2), denying the first hypothesis of this survey of prevalence equality between the two tests. Regarding the presence of anti-BVDV Ab, it was observed that for the samples considered positive, the iELISA agreed with the VN test in $98.73 \%(155 / 157)$ cases, considering this the correct positive value. Among the total number of negative samples, the results of iELISA and the VN agreed in $74.07 \%(180 / 243)$ cases, considering this the correct negative value. In this sense, iELISA presented $25.93 \%(63 / 243)$ of the false-positive samples and $1.27 \%(2 / 157)$ of the false-negative samples (Table 5). It should be noted that the BVDV-2 strain was not evaluated in the VN test. With that in mind, the false-positive samples may not all be, in fact, false-positive. 
Table 5. Results of iELISA BVDV Total Ab Test against virus neutralization (VN) in Nelore breed cattle reared in the Pará state.

\begin{tabular}{cccc}
\hline \multirow{2}{*}{ VN } & \multicolumn{2}{c}{ iELISA BVDV Total Ab Test } & \multirow{2}{*}{ TOTAL } \\
\cline { 2 - 3 } & Positive (\%) & Negative (\%) & 39.25 \\
Positive (\%) & 38.75 & 0.50 & $(157 / 400)$ \\
Negative (\%) & $(155 / 400)$ & $(2 / 400)$ & 60.75 \\
& 15.75 & 45.00 & $(243 / 400)$ \\
TOTAL & $(63 / 400)$ & $(180 / 400)$ & 100.00 \\
& 54.50 & 45.50 & $(400 / 400)$ \\
\hline
\end{tabular}

iELISA, indirect enzyme-linked immunosorbent assay; BVDV, bovine viral diarrhea virus, Ab, antibody.

The hypothesis that the iELISA has higher Se and Sp relative to the VN test was partially proven since a Se of $98.72 \%$ and $\mathrm{Sp}$ of $74.07 \%$ for the iELISA test were observed. Table 6 shows the results of $\mathrm{Se}, \mathrm{Sp}$, positive predictive value, and negative predictive value for the iELISA. The Se result found in the present study was higher than $96.3 \%$ and the Sp was less than $99.5 \%$, different from what is reported by the manufacturer. The high Se found in the present study indicates that the iELISA has a good ability to identify anti-BVDV Ab titers. As for the $\mathrm{Sp}$, it is assumed that the value was lower in this study because only the BVDV-1 strain (NADL) was used in the VN test, whereas the iELISA assay has high Se and Sp for the detection of anti- BVDV-1 and anti-BVDV-2 Ab, which probably explains the $25.93 \%$ of false-positive samples.

Table 6. Values of sensitivity (\%), specificity (\%), positive predictive value (\%), and negative predictive value (\%) of iELISA BVDV Total Ab Test.

\begin{tabular}{lc}
\hline & iELISA BVDV Total Ab Test \\
\hline Sensitivity (\%) & 98.72 \\
Specificity (\%) & 74.07 \\
Positive predictive value (\%) & 71.10 \\
Negative predictive value (\%) & 98.90 \\
\hline
\end{tabular}

iELISA, indirect enzyme-linked immunosorbent assay; BVDV, bovine viral diarrhea virus, Ab, antibody.

Larska et al. (2013) compared the performance of two commercially available iELISA kits: kit 1 BVDV-Ab ELISA Svanova Biotech versus kit 2 BVDV Total Ab Test IDEXX) in the detection of $A b$ against BVDV-1 and BVDV-2 in serum samples from calves experimentally infected with BVDV-1 and with an atypical strain of pestivirus and reported results for kits 1 and 2 of Se of $98.1 \%$ and $90.4 \%$ and $\mathrm{Sp}$ equal to $80.7 \%$ and $88.6 \%$, respectively. These data are similar to the results of the present study with cattle naturally infected by BVDV, which emphasizes the possibility that anti-BVDV-2 reactive animals were present in the studied herd. Therefore, there is a need for more studies on the prevalence of this disease in Pará state and the verification of the presence of atypical strains of pestiviruses disseminated on these herds.

Based on the data obtained from the iELISA test for the detection of anti-BVDV Ab, it was noted that the test could detect $71.10 \%$ of the BVDV-1 positive animals when they were positive. Likewise, the iELISA assay determined that $98.90 \%$ of the animals were BVDV-negative when they did not have the virus (Table 6). This may be extremely relevant when selecting truly negative animals for inclusion in programs for the adoption of biotechniques for reproduction (e.g., fixed time artificial insemination, embryo transfer, and in vitro embryo production) where the use of seropositive cows for BVDV could compromise the effectiveness of such programs. 


\section{Conclusions}

BVDV infection is present in Nelore female cows raised in both mesoregions studied (Metropolitan Region of Belém and Northeast of Pará). The hypothesis that the iELISA presents higher $(>90 \%)$ Se and $\mathrm{Sp}$ than the VN was partially confirmed. Thus, due to its higher Se and medium $\mathrm{Sp}$ relative to the $\mathrm{VN}$ test, the iELISA presents a higher prevalence in the detection of anti-BVDV Ab in bovine serum. Despite the higher prevalence, the iELISA is shown as a viable alternative for the detection of $\mathrm{Ab}$ against BVDV in the serum of naturally infected cattle. Agility and practicality, combined with high Se, are desirable characteristics for a test to be used as a screening exam aimed at identifying the seroreactive animals in large herds of beef cattle and guaranteeing a safe seroepidemiological diagnosis.

\section{Acknowledgements}

The present research had financial support from the CT - TRANSVERSAL ACTION / Public Call MCT / CNPq / MEC / CAPES - Transversal Action no. 06/2011 - Casadinho / Procad Process n ${ }^{\circ}$ 552215 / 2011-2.

\section{References}

ALEXANDRINO, B.; DIAS, F. C.; OLIVEIRA, M. C.; AFFONSO, I. B.; PEREIRA, G. T.; SAMARA, S. I. Herpesvirus bovino associado à diarreia viral bovina e à leucose enzoótica bovina. Ars Veterinária, Jaboticabal, v. 27, n. 3, p. 168-174, 2011.

ALTAMIRANDA, E. A. G.; KAISER, G. G.; WEBER, N.; LEUNDA, M. R.; PECORA, A.; MALACARI, D. A.; MORÁN, O.; CAMPERO, C. M.; ODEÓN, A. C. Clinical and reproductive consequences of using BVDV-contaminated semen in artificial insemination in a beef herd in Argentina. Animal Reproduction Science, Amsterdam, v. 133, n. 3-4, p. 146-152, 2012.

BAKER, J.C. The clinical manifestations of bovine viral diarrhea infection. Veterinary Clinics of North America: Food Animal Practice, New York, v. 11, n. 3, p. 425-445, 1995.

BAUERMANN, F. V.; HARMON, A.; FLORES, E. F.; FALKENBERG, S. M.; REECY, J. M.; RIDPATH, J. F.
In vitro neutralization of HoBi-like viruses by antibodies in serum of cattle immunized with inactivated or modified live vaccines of bovine viral diarrhea viruses 1 and 2 . Veterinary Microbiology, Amsterdam, v. 166, n. 1-2, p. 242-245, 2013.

BRITO, W. M. E. D.; ALFAIA, B. T.; CAIXETA, S. P. M. B.; RIBEIRO, A. C. C.; MIRANDA, T. M. T.; BARBOSA, A. C. V. C.; BARTHASSON, D. L.; LINHARES, D. C.; FARIA, B. O. Prevalência da infecção pelo vírus da diarreia viral bovina (BVDV) no estado de Goiás, Brasil. Revista de Patologia Tropical, Goiânia, v. 39, n. 1, p. 7-19, 2010.

BROWNLIE, J. The pathogenesis of bovine viral diarrhea virus infections. Revue Scientifique Et Technique, OIE, Paris, v. 9, n. x, p. 43-59, 1990.

CHAVES, N. P.; BEZERRA, D. C.; SOUSA, V. E.; SANTOS, H. P.; PEREIRA, H. M. Frequência de anticorpos e fatores de risco para a infecção pelo vírus da diarreia viral bovina em fêmeas bovinas leiteiras não vacinadas na região amazônica maranhense, Brasil. Ciência Rural, Santa Maria, v. 40, n. 6, p. 1448-1451, 2010.

DIAS, F. C.; ALEXANDRINO, B.; MEDEIROS, A. S. R.; PEREIRA, G. T.; OLIVEIRA, M. C.; SAMARAI, S. I. Comparação dos testes de virusneutralização contra os genótipos 1 e 2 do vírus da diarreia viral bovina (BVDV1 e BVDV-2) em bovinos de rebanhos naturalmente infectados. Ciência Rural, Santa Maria, v. 40, n. 4, p. 913-920, 2010.

DUBOVI, E. J. Laboratory diagnosis of bovine viral diarrhea vírus. Journal of Biological Standardization, London, v. 41, n. 1, p. 8-13, 2013.

FLORES, E. F.; WEIBLEN, R.; VOGEL, F. S. F.; ROEHE, P. M.; ALFIERI, A. A.; PITUCO, E. M. A infecção pelo vírus da diarreia viral bovina (BVDV) no Brasil - histórico, situação atual e perspectivas, Pesquisa Veterinária Brasileira, Rio de Janeiro, v. 25, n. 3, p. 125134, 2005.

FREITAS, E. J. P.; LOPES, C. E. R.; SANTOS, T. C. C.; FONSECA, S. C. C.; SOARES, R. R.; MOURA FILHO, J. M.; SANTOS, H. P.; PEREIRA, H. M. Detecção de anticorpos contra o BVDV (vírus da diarreia viral bovina) em rebanhos de corte não vacinados no município de Açailândia, Maranhão-Brasil. Revista de Medicina Veterinária e Zootecnia, Belo Horizonte, v. 18, n. 4, p. 790-792, 2011.

FULTON，R. W.; SALIKI，J. T.; BURGE，L. J.; D'OFFAY, J. M.; BOLIN, S. R.; MAES, R. K.; BAKER, J. C.; FREY, M. L. Neutralizing antibodies to type 1 and 2 bovine viral diarrhea viruses: detection by inhibition of viral cytopathology and infectivity by immunoperoxidase 
assay. Clinical and Diagnostic Laboratory Immunology, Washington, v. 4, p. 380-383, 1997.

GONDA, M. G.; FANG, X.; PERRY, G. A.; MALTECCA, C. Measuring bovine viral diarrhea virus vaccine response: Using a commercially available ELISA as a surrogate for serum neutralization assays. Vaccine, Tokyo, v. 30, n. 46, p. 6559-6563, 2012.

GOYAL, S. M. Diagnosis. In: GOYAL, S. M.; RIDPATH, J. F. Bovine viral diarrhea virus: diagnosis, management and control. Iowa: Blackwell Publishing Professional, 2005. p. 197-208.

GROOMS, D. L. Reproductive losses caused by bovine viral diarrhea virus and leptospirosis. Theriogenology, Stoneham, v. 66, n. 3, p. 624-628, 2006.

HOUE, H. Epidemiological features and economical importance of bovine virus diarrhoea virus (BVDV) infections. Veterinary Microbiology, Amsterdam, v. 64, n. 2-3, p. 89-107, 1999.

JUNQUEIRA, J. R. C.; FREITAS, J. C.; ALFIERI, A. F.; ALFIERI, A. A. Avaliação do desempenho reprodutivo de um rebanho bovino de corte naturalmente infectado com o BoHV-1, BVDV e Leptospira hardjo. Semina: Ciências Agrárias, Londrina, v. 27, n. 3, p. 471-480, 2006.

KAREN, A. M.; DARWISH, S.; RAMOUN, A.; TAWFEEK, K.; HANH, N. V.; SOUSA, N. M.; SULON, J.; SZANCI, O.; BECKERS, J. F. Accuracy of transrectal palpation for early pregnancy diagnosis in Egyptian buffaloes. Tropical Animal Health Production, Dordrecht, v. 43, n. 1, p. 5-7, 2011.

LARSKA, M.; POLAK, M. P.; LIUC, L.; ALENIUSA, $S$. Comparison of the performance of five different immunoassays to detect specific antibodies against emerging atypical bovine pestivirus. Journal of Virological Methods, Amsterdam, v. 187, n. 1, p. 103109, 2013.

LETELLIER, C.; KERKHOFS, P. Real-time PCR for simultaneous detection and genotyping of bovine viral diarrhea virus. Journal of Virological Methods, Amsterdam, v. 114, n. 1, p. 21-27, 2003.

MARQUES, A. L. A.; LISANKA, A. M.; AGUIAR, G. M. N.; WEBER, M. N.; SIMÕES, S. V. D.; AZEVEDO, S.S. Detecção do virus 'HoBi'-like (BVDV-3) em bovino no semiárido do Estado da Paraíbal Pesquisa Veterinária Brasileira, Rio de Janeiro, v. 36, n. 11, p. 1081-1086, 2016.
WORLD ORGANISATION FOR ANIMAL HEALTH OIE. Bovine viral diarrhoea. Section 2.4, Chapter 2.4.7. Paris, France: World Organisation for Animal Health, 2015. (Manual of Diagnostic Tests and Vaccines for Terrestrial Animals). Available at: <http://www.oie.int/ fileadmin/Home/eng/Health_standards/tahm/2.04.07 BVD.pdf $>$. Accessed at: 18, ago. 2017.

PASQUALOTTO, E.; SEHNEM, S.; WINCK, C.A. Incidência de rinotraqueíte infecciosa bovina (IBR), diarreia viral bovina (BVD) e leptospirose em bovinos leiteiros da região oeste de Santa Catarina - Brasil. Revista em Agronegócio e Meio Ambiente, Maringá, v. 8, n. 2, p. 249-270, 2015.

QUINCOZES, C.G.; FISCHER, G.; HÜBNER, S.O.; VARGAS, G.D.A.; VIDOR, T.; BROD, C.S. Prevalência e fatores associados à infecção pelo vírus da diarréia viral bovina na região Sul do Rio Grande do Sul. Semina: Ciências Agrárias, Londrina, v. 28, n. 2, p. 269-276, 2007.

REED, L. J.; MUENCH, H. A simple method of estimating fifty percent endpoints. The American Journal of Hygiene, Deerfield, v. 27, n. 3, p. 493-497, 1938.

RODNING, S. P.; GIVENS, M. D.; MARLEY, M. S. D.; ZHANG, Y.; RIDDELL, K. P.; GALIK, P. K.; HATHCOCK, T. L.; GARD, J. A.; PREVATT, J. W.; OWSLEY, W. F. Reproductive and economic impact following controlled introduction of cattle persistently infected with bovine viral diarrhea virus into a naive group of heifers. Theriogenology, Stoneham, v. 78, n. 7, p. 1508-1516, 2012.

SOUSA, V. E.; BEZERRA, D. C.; CHAVES, N. P.; SANTOS, H. P.; PEREIRA, H. M. Frequência de anticorpos e fatores de risco associados à infecção pelo vírus da diarreia viral bovina (BVDV) e herpesvírus bovino tipo 1 (bohv-1) em fêmeas bovinas leiteiras criadas em sistema de produção semi-intensivo. Revista Brasileira de Medicina Veterinária, Rio de Janeiro, v. 35, n. 1, p. 21-25, 2013.

STURZA, D. A. F.; ANZILIERO, D.; WEIBLEN, R.; FLORES, E. F. Testes de ELISA e vírus-neutralização na detecção de anticorpos contra o vírus da diarreia viral bovina no leite. Pesquisa Veterinária Brasileira, Rio de Janeiro, v. 31, n. 11, p. 985-990, 2011.

VILCEK, S.; PATON, D. J.; DURKOVIC, B.; STROJNY, L.; IBATA, G.; MOUSSA, A.; LOITSCH, A.; ROSSMANITH, W.; VEGA, S.; SCICLUNA, M. T.; PALFI, V. Bovine viral diarrhoea virus genotype 1 can be separated into at least eleven genetic groups. Archives of Virology, Viena, v. 146, n. 1, p. 99-115. 2001. 